\title{
Characterization of BSL6 isolates isolated from honeybee hive and to determine its antibacterial activity
}

\author{
LENNI FITRI $^{1, \boldsymbol{}}$, YEKKI YASMIN ${ }^{1}$, FAUZIAH ${ }^{1}$, DWI ANDRI SEPTIANI ${ }^{2}$, SUHARTONO $^{1}$ \\ ${ }^{1}$ Departement of Biology, Faculty of Matematics and Natural Sciences, Universitas Syiah Kuala. Jl. Syech Abdurrauf No. 3, Kopelma Darussalam, Syiah \\ Kuala, Banda Aceh 23111, Aceh, Indonesia. Tel.: +62- 651-8012505, `email:lennifitri@unsyiah.ac.id \\ ${ }^{2}$ Biology Program, Faculty of Mathematics and Natural Sciences, Universitas Syiah Kuala. Jl. Syech Abdurrauf No. 3, Kopelma Darussalam, Syiah \\ Kuala, Banda Aceh 23111, Aceh, Indonesia
}

Manuscript received: 11 September 2020. Revision accepted: 26 September 2020.

\begin{abstract}
Fitri L, Yasmin Y, Fauziah, Septiani DA, Suhartono. 2020. Characterization of BSL6 isolates isolated from honeybee hive and to determine its antibacterial activity. Biodiversitas 21: 4859-4865. This study was aimed to characterize BSL6 isolate of bacteria isolated from honeybee hive, and to determine its antimicrobial activity against Staphylococcus aureus and Escherichia coli. In addition, the Minimum Inhibitory Concentration (MIC) value of BSL6 isolate was determined against S. aureus, and content of secondary metabolic compounds was also determined. Characterization was conducted in this study on the basis of morphological observations, physiological tests, and 16S rDNA. The method used in determining MIC value was completely randomized design (CRD) then analyzed by ANOVA test using SPSS application and followed by Tukey test. The analysis conducted to determine the content of secondary metabolites was descriptive type. The results showed that BSL6 isolate morphologically and physiologically belonged to the genus Bacillus, and 16S rDNA test results showed that the isolate had the highest similarity with Bacillus siamensis strain 64X-5. BSL6 isolate was able to inhibit the growth of $S$. aureus with inhibition zone diameter of $17.87 \mathrm{~mm}$. MIC value of BSL6 against $S$. aureus was at a concentration of $12.5 \%$. The content of secondary metabolite compounds from BSL6 extract was saponins.
\end{abstract}

Keywords: BSL6, characterization, honeybee hive, Minimum Inhibitory Concentration (MIC), secondary metabolites

\section{INTRODUCTION}

Honeybee hive is composed of propolis, a natural product derived from plant resins collected by honeybee. Propolis has been used as medicine by the public for centuries. Propolis has attracted attention of researchers in recent years because of its potential as a medicinal and cosmetic product (Lofty 2006). Research by Dantas Silva et al. (2017) showed that the properties of various Brazilian propolis extracts have antimicrobial, antioxidant, and cytotoxic activity.

The hive of honeybee (Apis cerana) has been investigated and proven to have antimicrobial activity. Part of the hive has different chemicals compounds which can act as an antimicrobial agent. This shows that honeybee hives has the potential to be used as an antibiotic to inhibit growth and to kill various pathogenic bacteria so that the quality of honey still maintained. Honeybee hive compounds with antimicrobial activity can be used as a source of natural antimicrobials (Reybroeck et al. 2012). A study conducted by Yuliana et al. (2015) showed that honeybee hive had antimicrobial activity against pathogenic microbes with minimal inhibitory concentration off $1 \%(\mathrm{v} / \mathrm{v})$.

Microbial resistance is the inability of antimicrobials to kill microbes. Until now, microbial resistance towards antibiotics is increasing continuously. Antibiotic resistance occurs when bacteria change in certain ways that reduce or eliminate the effectiveness of antibiotics used as drugs (Bisht et al. 2009). This lead to the emergence of new pathogenic microbes that are resistant to antibiotics. All of these become the primary reason for the search of new, inexpensive and sustainably available antibiotics in large quantities.

Previous research results succeeded in obtaining BSL6 isolate from honeybee hive, however, the characterization of the isolate and its antibacterial ability had not been carried out yet. Based on this, this study was carried out to characterize BSL6 isolate based on its morphologically, biochemical test and at molecular using $16 \mathrm{~S}$ rDNA amplification and to determine the ability of this isolate to inhibit the growth of Staphylococcus aureus and Escherichia coli. This study also aimed to determine minimum inhibitory concentration (MIC) value and secondary metabolite content of BSL6 which might have antibacterial properties.

\section{MATERIALS AND METHODS}

\section{Bacterial isolation}

A total of 1 gram piece of hive was soaked with sterile distilled water for one minute, then the surface was soaked with $70 \%$ alcohol for three minutes and soaked again with sterile distilled water for one minute. Beehive was cut using a sterile knife and mashed using mortar and pestle, then added with $5 \mathrm{~mL}$ of sterile distilled water are and homogenized using vortex for three minutes. A total of 100 $\mu \mathrm{L}$ of the solution from the suspension was taken using micropipette and spread into NA medium. The sample was 
incubated at $37^{\circ} \mathrm{C}$ for 48 hours (Promnuan et al. 2009). The isolate obtained then purified and identified.

\section{Bacteria identification}

Identification was conducted by referring to Bergey's Manual of Determinative Bacteria (Holt et al. 1994) and the Manual for the Identification of Medical Bacteria (Cowan and Steels 1993). Characterization of bacteria isolates obtained was carried out by macroscopic, microscopic, biochemical test, and $16 \mathrm{~S}$ rDNA test. Macroscopic characterization was carried out by observing morphology of bacterial colony including shape, margin, color, and elevation of the colony. Biochemical test of BSL6 isolate was conducted for further identification. Biochemical tests conducted include catalase test, motility test, indole test, Methyl Red (MR) test, Simmons Citrate test, and TSIA test.

\section{Identification of BSL6 by analysis of 16S rRNA gene}

DNA Genome isolation of BSL6 was carried out using Wizard Genome Purification Kit (Promega, USA). Amplification was performed using PCR Thermal Cycler T100. The primers used for PCR process were universal primers pair Bact 27F (forward) (5 'AGA GTT TGA TCM TGG CTC AG 3') and UniB 1492R (reverse) (5 'GGT TAC CTT GTT ACG ACT T 3').

Sequencing process was carried out after amplification, by sending PCR DNA product to 1st Base via PT. Genetics Science. The sequenced DNA chromatogram was edited using DNA Baser Assembler v5.15.0 software. The results of DNA sequencing were then analyzed using the Basic Alignment Search Tools Nucleotide (BLAST-N) program through NCBI online media to find the similarity of the $16 \mathrm{~S}$ rRNA gene nucleotide sequence with other microorganisms found in GenBank. Then processed using Molecular Evolutionary Genetics Analysis Version X (MEGA X) application (Rau et al. 2018).

\section{Phylogenetic tree analysis}

Phylogenetic tree analysis was carried out in two stages, namely primary sequences of Bact $27 \mathrm{~F}$ and UniB 1492R on BSL6 isolates from the sequencing using DNA Baser Assembler application. Then the sequences that had similarities to BSL6 sequences were aligned using MEGA $X$. The results of the alignment then constructed with phylogenetic tree using MEGA $X$ with the NeighborJoining (NJ) approaching method with bootstrap value of 1000 replicates.

\section{Antimicrobial activity test}

Test bacteria ( $S$. aureus and $E$. coli) were incubated for 24 hours at $37^{\circ} \mathrm{C}$ in slanted Nutrient Agar (NA) medium. The tested bacteria were then taken using inoculation loop and added into $0.9 \% \mathrm{NaCl}$ solution. Furthermore, as much as $1 \mathrm{~mL}$ of bacteria suspension was taken and spreaded on the surface of Mueller Hinton Agar (MHA) medium and let it settle for 5 minutes so that bacteria would stick to the medium.

Honeybee hive bacteria isolates were taken using cork borer and transferred into MHA medium upside down so that test bacteria facing towards the medium and then incubated at room temperature for 24 hours. Observations were carried out by measuring the diameter of clear zone or inhibitory zone formed using a caliper.

\section{Bacteria extraction}

Total 5 discs ( $5 \mathrm{~mm}$ diameter) of NA medium having inoculated with BSL6 were taken with the help of a cork borer, put into Erlenmeyer flask containing $150 \mathrm{~mL}$ of Nutrient Broth (NB) medium, and then incubated in orbital shaker for 48 hours at a speed of $100 \mathrm{rpm}$ at room temperature. The cell biomass was separated using filter paper then centrifuged at $3000 \mathrm{rpm}$ for 60 minutes to obtain supernatant. The supernatant obtained was filtered again using filter paper to obtain crude extract of the bacteria which would be used for further tests (Duniaji et al. 2016).

\section{Preparation of bacterial extract concentrations}

A total of $25 \mathrm{~mL}$ of BSL6 extract was taken in a sterile Erlenmeyer flask then added with $25 \mathrm{~mL}$ of sterile NB medium so that the extract with a concentration of $50 \%$ in $50 \mathrm{~mL}$ was obtained. Furthermore, the concentration was continued to obtain concentration of $25 \%, 125 \%$ and $6.25 \%$.

\section{Minimum Inhibitory Concentration (MIC) test}

Antibacterial activity of beehive bacteria extract was carried out by turbidity measurement method using spectrophotometer analysis. Minimum inhibitory concentration value was determined using pour plate method. The isolate was tested against Escherichia coli. The density of $E$. coli suspension was $10^{6} \mathrm{CFU} / \mathrm{mL}$. Preparation of the suspension at this density was carried out using McFarland 0.5 method consisting of $9.95 \mathrm{~mL}$ of $1 \% \mathrm{H}_{2} \mathrm{SO}_{4}$ solution and $0.05 \mathrm{~mL}$ of $1.175 \% \mathrm{BaCl}$ solution, which was equivalent to bacteria density of $10^{8} \mathrm{CFU} / \mathrm{mL}$ (Sutton 2011).

The suspension of tested bacteria was made by taking E. coli from NA medium which had been incubated for 24 hours in a tube containing $10 \mathrm{~mL}$ of $0.9 \% \mathrm{NaCl}$ and then homogenized using vortex. The homogenized suspension then equalized its turbidity by measuring it using spectrophotometer with a wavelength of $630 \mathrm{~nm}$. Absorbance value of 0.08-0.1 was equivalent to McFarland solution of 0.5 or $10^{8} \mathrm{CFU} / \mathrm{mL}$. The bacteria suspension that has been made then diluted by taking $0.1 \mathrm{~mL}$ of the bacterial suspension and put in a tube containing $9.9 \mathrm{~mL}$ of $0.9 \% \mathrm{NaCl}$ solution and then vortexed, so that the bacterial density is $10^{6} \mathrm{CFU} / \mathrm{mL}$ (Oonmetta-aree et al. 2005).

A total of 14 test tubes containing $8.8 \mathrm{~mL}$ sterile NB medium were prepared. The first tube was added with 1 $\mathrm{mL}$ of sterile NB media and $200 \mu \mathrm{L}$ of $E$. coli suspension. The second tube was added with $1 \mathrm{~mL}$ of Amoxicillin antibiotic and $200 \mu \mathrm{L}$ of $E$. coli suspension. The $3^{\text {rd }}-7^{\text {th }}$ tube was added with $1 \mathrm{~mL}$ of BSL6 extract with a concentration of $100 \%, 50 \%, 25 \%, 12.5 \%$, and $6.25 \%$ respectively, then each tube was added with $200 \mu \mathrm{L}$ of $E$. coli suspension. This treatment was repeated 3 times.

All tubes were vortexed and $2 \mathrm{~mL}$ of each treatment was taken in a cuvette to measure Optical Density (OD) 
value using spectrophotometer with a wavelength of 630 $\mathrm{nm}$. All tubes were incubated at $37^{\circ} \mathrm{C}$ for 18 hours. The OD value was measured again after incubation by taking $2 \mathrm{~mL}$ of each treatment in a cuvette and measuring the OD value using spectrophotometer with a wavelength of $630 \mathrm{~nm}$. The difference between OD values of the suspension before and after incubation were compared (Munfaati et al. 2014).

Furthermore, pour plate method was used to calculate the number of colonies that have grown from the incubated suspension. All bacterial suspensions that had been incubated were taken as much as $10 \mu \mathrm{L}$ each for dilution, then put into a $1.5 \mathrm{~mL}$ Eppendorf tube that already contained $990 \mu \mathrm{L}$ of $0.9 \% \mathrm{NaCl}$. The dilution was done up to $10^{-6}$. A total of $100 \mu \mathrm{L}$ from the $10^{-6}$ dilution from each treatment were taken and put into a sterile petri dish, and then Plate Count Agar (PCA) medium was poured into the petri dish and waited until it solidified. Furthermore, it was incubated at $37^{\circ} \mathrm{C}$ for 24 hours. The number of colony growths in PCA medium was calculated using Colony Counter. The data obtained then analyzed using one way ANOVA test through SPSS application to see significant differences and to determine the value of MIC (Munfaati et al. 2014).

\section{RESULTS AND DISCUSSION}

\section{Characterization of Isolate}

Based on the observations bacteria isolates isolated from bee hive had circular colony shape, smooth margin, cream color, and flat elevation. Morphological characterization of bacteria was characterized based on Prescott's Microbiology book (Figure 1).

Microscopic characterization was carried by using Gram staining, which aimed to observe the shape of bacterial cells and divide the bacteria into Gram positive and Gram negative bacteria. The results showed that BSL6 was belong to Gram positive bacteria and had Coccobacilli cell shape. The results of biochemical test of BSL6 could be seen in Table 1
Based on the characteristics observed, BSL6 isolate belonged to the genus Bacillus. Cowan and Steels (1993) stated that bacterium from genus Bacillus has rod-shaped and straight cells, some in the form of coccobacilli on nonselective agar media, with size of 0.5-2.5 x 1.2-10 $\mu \mathrm{m}$, and often arranged in pairs or chains, with round or square ends. The physiological abilities were diverse, usually nonmotile, if motile by peritrichous flagella, catalase and oxidase-positive, negative methyl red, negative indole, negative nitrate and optimum growth at $30-37^{\circ} \mathrm{C}$. Bacillus sp. are aerobic or facultative anaerobes, very sensitive to heat, $\mathrm{pH}$, and salinity. Bacillus sp. was widespread in various habitats, several species were pathogens to vertebrates or invertebrates.

The bacteria obtained were in accordance with several previous studies. Piccini et al. (2004) also found various types of bacteria belong to the genus Bacillus from the beehive of Apis sp. Perez et al. (2013) also added that the beehive was dominated by bacteria from Bacillus $\mathrm{sp}$.

Molecular identification based on partial sequences of $16 \mathrm{~S}$ rRNA showed that BSL6 had the highest similarity with Bacillus siamensis strain 64X-5, Bacillus subtilis strain MDA1, Bacillus subtilis strain MDA2, Bacillus amyloliquefaciens strain 15535, and Bacillus amyloliquefaciens strain ORE3 with a query score of 2412, e-value of 0.0 and identity percentage value of $99.77 \%$.

Table 1. Biochemical test of BSL6

\begin{tabular}{lc}
\hline Test & BSL6 \\
\hline Catalase & - \\
Motility & - \\
Indole & - \\
MR & - \\
Simmons Citrate & + \\
TSIA: & \\
Glucose & + \\
Glucose dan Sucrose & - \\
H2S & - \\
Gas & - \\
\hline
\end{tabular}

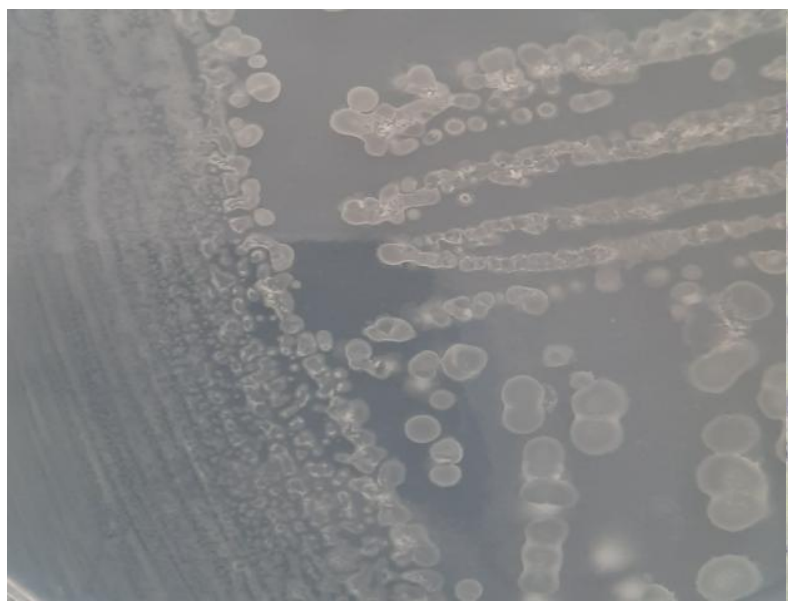

A

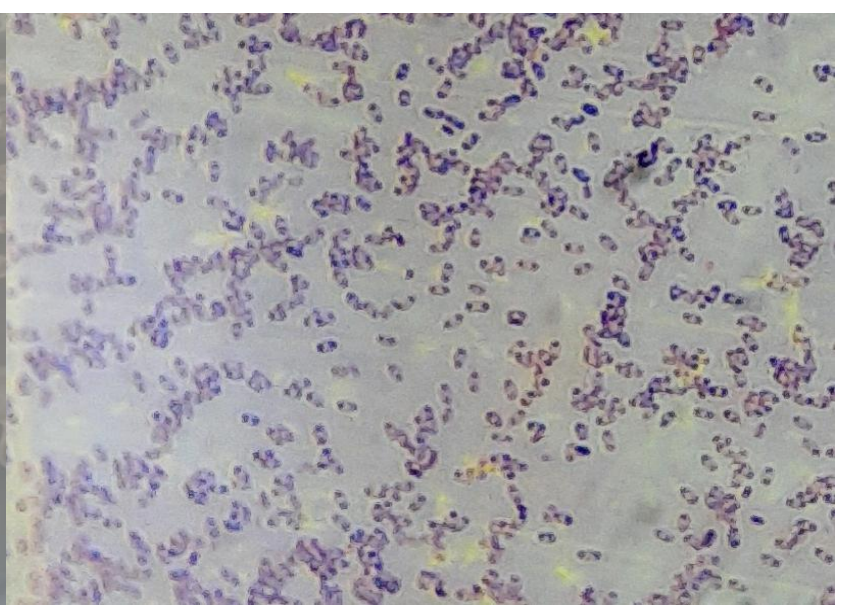

B

Figure 1. Macroscopic and microscopic morphology of BSL6 isolates in NA medium. A.Macroscopic; B.Microscopic 
Table 2. Alignment data of several organisms from BLAST with BSL6

\begin{tabular}{lcccccc}
\hline \multicolumn{1}{c}{ Description } & $\begin{array}{c}\text { Max } \\
\text { score }\end{array}$ & $\begin{array}{c}\text { Total } \\
\text { score }\end{array}$ & $\begin{array}{c}\text { Query } \\
\text { cover }\end{array}$ & E value & $\begin{array}{c}\text { Ident } \\
(\%)\end{array}$ & Accession \\
\hline Bacillus siamensis strain 64X-5 & 2412 & 2412 & $99 \%$ & 0.0 & 99.77 & MN462850.1 \\
Bacillus subtilis strain MDA1 & 2412 & 2412 & $99 \%$ & 0.0 & 99.77 & MN493719.1 \\
Bacillus subtilis strain MDA2 & 2412 & 2412 & $99 \%$ & 0.0 & 99.77 & MN493754.1 \\
Bacillus amyloliquefaciens strain 15535 & 2412 & 2412 & $99 \%$ & 0.0 & 99.77 & MN630201.1 \\
Bacillus amyloliquefaciens strain ORE3 & 2412 & 2412 & $99 \%$ & 0.0 & 99.77 & MN685260.1 \\
\hline
\end{tabular}

According to NCBI (2019), B. siamensis strain 64X-5 is a soil-borne bacteria. According to Sumpavapol et al. (2010), B. siamensis is a bacterium from the genus Bacillus which belong to Gram-positive, facultatively anaerobic, rod-shaped bacteria, with a size of 0.3-0.661 $\mu \mathrm{m}, 5-3 \mu \mathrm{m}$, and $5 \mu \mathrm{m}$. B. siamensis cells can be single, paired, and sometimes in the form of short chains. The ellipsoidal endospores of this bacteria are produced in the middle or subterminal bulging sporangia. Colonies of $B$. siamensis are creamy white, slimy, clear, raised, have entire margins, with colony diameter of 3-4 $\mathrm{mm}$ after 2 days incubation at $37^{\circ} \mathrm{C}$ in TSA media.

B. siamensis in liquid media was in the form of a thin film on medium surface and the rest was shaped like clouds in the media. This bacteria produced catalase but did not produce oxidase. Voges-Proskauer test results showed positive results in reducing nitrates, positive results in hydrolysis of casein, aesculin, DNA gelatin, and starch. $B$. siamensis could grow at a temperature ranged from $4^{\circ} \mathrm{C}$ to $55^{\circ} \mathrm{C}$ and the optimal temperature was $37^{\circ} \mathrm{C}$. B. siamensis could grow with $0-14 \%(\mathrm{w} / \mathrm{v}) \mathrm{NaCl}$ and could grow optimally without $\mathrm{NaCl}$. B. siamensis could grow in environments with $\mathrm{pH} 4.5$ and 9.0 and could grow optimally at pH 6-7 (Sumpavapol et al. 2010).

Claverie and Notredame (2007) stated that the expectation value (E-value) was the value used to determine the similarity of sequencing results with the data contained in GenBank. Identical sequences have zero evalue. If the e-value is closer to one, the lower the level of similarity between the sequencing results and the data contained in GenBank. According to Bosshard et al. (2003), in identifying species of bacteria, there were three criteria from the query cover value, namely the first isolates could be classified as the same species if the query cover value was $\geq 99 \%$, the second isolate could be in the same genus if the cover query value ranges from $95 \%$ to $99 \%$ and the third isolate could be classified in the same family if the query cover value was $\leq 95 \%$. Meanwhile, according to Drancourt et al. (2000); Kadaikunnan et al. (2015), identification could be seen from the value of identity percentage. Identity percentage value $\geq 97 \%$ indicated that identification up to genus level, identity percentage value> $99 \%$ indicated that identification up to species level, and identity percentage value $<97 \%$ indicated a low homology level from sequencing results with sequences contained in the database.
Based on phylogenetic tree analysis using NeighborJoining (NJ) approach with a bootstrap value of 1000 replicates, BSL6 isolate formed a monophyletic group with one strain from the genus Bacillus, namely Bacillus amyloliquefaciens strain ORE3. BSL6 isolate had the closest relationship with the $B$. amyloliquefaciens strain ORE3 with a bootstrap percentage value of $100 \%$ (Figure 2.).

\section{Antibacterial activity test}

Antibacterial activity test was conducted to observe and to measure inhibition zone of bacterial isolates isolated from honeybee. The results showed that BSL6 isolate was not able to inhibit the growth of $E$. coli, but was able to inhibit the growth of $S$. aureus with inhibition zone of $17.87 \mathrm{~mm}$. (Figure 3). According to Lay (1994), the ability of antimicrobial agents to inhibit microbial growth could be determined by measuring inhibition zone formed around the disc.

BSL6 isolate had strong antibacterial activity against tested bacteria. Based on the study by Davis and Stout (1971), the result showed that the measurement of antibacterial inhibition zone could be divided into several categories, namely very strong if the inhibition zone diameter was $>20 \mathrm{~mm}$, strong (sensitive) if the inhibition zone diameter was $10-20 \mathrm{~mm}$, intermediate if the inhibition zone diameter was $5-10 \mathrm{~mm}$, and weak (resistant) if the inhibition zone was $<5 \mathrm{~mm}$. Bhorgin and Uma (2014) stated that the size of inhibition area was influenced by the growth rate of microorganisms, the ability and diffusion rate of active ingredients in the medium, the sensitivity of microorganisms towards active substances, and the thickness and viscosity of the medium.

Table 3. The average results of BSL6 treatment against Staphylococcus aureus

\begin{tabular}{|c|c|c|}
\hline \multirow{2}{*}{ Treatment } & \multicolumn{2}{|c|}{ Staphylococcus aureus } \\
\hline & Colony & OD \\
\hline $\mathrm{K}+$ & $0.0^{\mathrm{a}} \pm 0.0$ & $0.0710^{\mathrm{a}} \pm 0.0030$ \\
\hline $\mathrm{K}-$ & $321.0^{\mathrm{a}} \pm 41.0$ & $0.1295^{\mathrm{a}} \pm 0.0025$ \\
\hline $6.25 \%$ & $354, .0^{\mathrm{a}} \pm 229.0$ & $0.1340^{\mathrm{a}} \pm 0.0620$ \\
\hline $12.5 \%$ & $80.0^{a} \pm 20.0$ & $0.1910^{\mathrm{a}} \pm 0.0060$ \\
\hline $25 \%$ & $54.0^{\mathrm{a}} \pm 17, .0$ & $0.1890^{\mathrm{a}} \pm 0.0110$ \\
\hline $50 \%$ & $0.0^{\mathrm{a}} \pm 0.0$ & $0.1860^{\mathrm{a}} \pm 0.0100$ \\
\hline $100 \%$ & $0.0^{\mathrm{a}} \pm 0.0$ & $0.1705^{\mathrm{a}} \pm 0.0055$ \\
\hline
\end{tabular}


Table 4. The content of secondary metabolite compounds in BSL6 isolate

\begin{tabular}{llll}
\hline Metabolite Content & Reagent & BSL6 & Observation \\
\hline Alkaloids & Mayer & - & There is no cream-colored precipitate \\
& Wagner & - & There is no brown precipitate \\
& Dragendorff & - & There is no red precipitate \\
Steroids & Liebermann-Burchard Test & - & There is no green color \\
Terpenoids & Liebermann-Burchard Test & - & There is no red color \\
Saponins & Aquadest & + & Foamy \\
Flavonoids & $\mathrm{HCl}$ dan Logam Mg & - & There is no reddish color \\
Phenolics & $\mathrm{FeCl}_{3}$ & - & There is no green color \\
Tannins & $\mathrm{FeCl}_{3}$ & - & There is no green color \\
\hline
\end{tabular}

Note: (+) showed positive result and (-) showed negative result

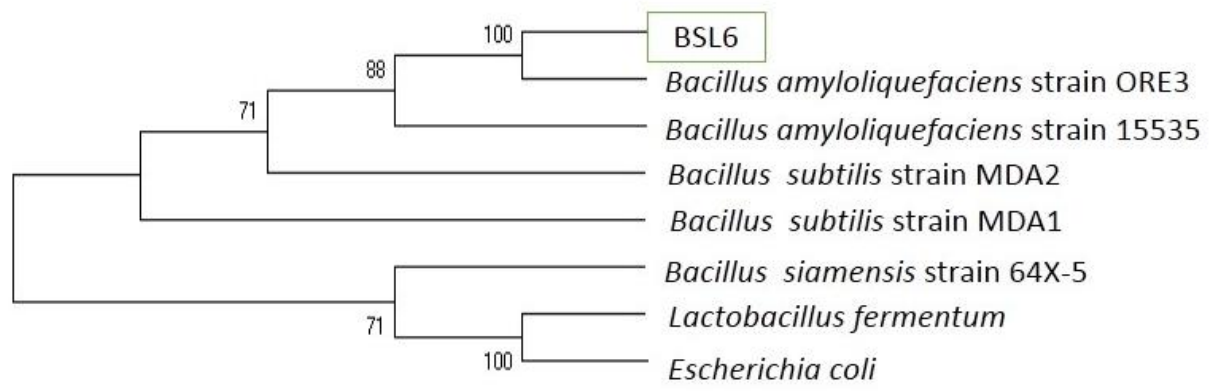

Figure 2. The results of phylogenetic tree reconstruction of BSL6 with several organisms from BLAST

BSL6 isolate was only able to inhibit the growth of $S$. aureus. This isolate produced secondary metabolites which were more suitable for Gram-positive bacteria than Gramnegative bacteria Dharmawan et al. (2009) stated that inhibition zone was formed because this isolate produced secondary metabolites. Inhibition zone was influenced by the difference in polarity of the compounds contained in bacteria.

\section{Minimum Inhibitory Concentration (MIC)}

Table 3 showed that BSL6 extract treatment affected total colony and OD value of $S$. aureus. However, if based on statistical analysis, BSL6 was not significantly different from total colony and OD values of $S$. aureus. The difference in superscripts values indicated that there were significant differences between each treatment.

Based on Table 3 all concentrations of BSL6 extract showed an effect towards total colonies of $S$. aureus, but concentration of $6.25 \%(354.0 \mathrm{a} \pm 229.0)$ had a higher mean value than negative control $(321.0 \mathrm{a} \pm 41.0)$ which indicated that concentration of $6.25 \%$ had no effect on the total colonies of $S$. aureus. Meanwhile, there was no significant difference in OD value because all concentrations showed the same superscript as positive control. MIC value of BSL6 against $S$. aureus was analyzed at a concentration of $12.5 \%$. The concentration at $12.5 \%$ had mean value of
$80.0 \mathrm{a} \pm 20.0$. The results of a study carried out by Soelama et al. (2015) showed that MIC value obtained with a concentration ratio of $1: 2(\mathrm{v} / \mathrm{v})$ was at a concentration of $6.25 \%$, the higher the concentration of the extract used, the greater the ability to inhibit the tested bacteria.

BSL6 extract with concentration of $6.25 \%$ could not inhibit the growth of $S$. aureus. This was presumably because at this concentration there were not too many secondary metabolites and there were still BSL6 bacterial cells, so that when the pouring plate was done BSL6 bacterial cells could still multiply which caused the total colony to be larger than the negative control. Bacterial cells that were still present in BSL6 extract were suspected because the extraction was not carried out with ethanol solvents, so that the BSL6 bacterial cells did not die. According to Nofiani et al. (2009), extraction using ethanol as the solvent could cause cell lysis. Lysed cells may cause secondary metabolite compounds to diffuse into the ethanol solvent.

This is in line with the study of Wachidah et al. (2016), where the effectiveness of an antibacterial was influenced by the concentration of substance given, the higher the concentration of the honey beehive bacterial extract solution given, the higher the active antibacterial substances in the solution, so that the ability to inhibit bacteria would be even greater. 


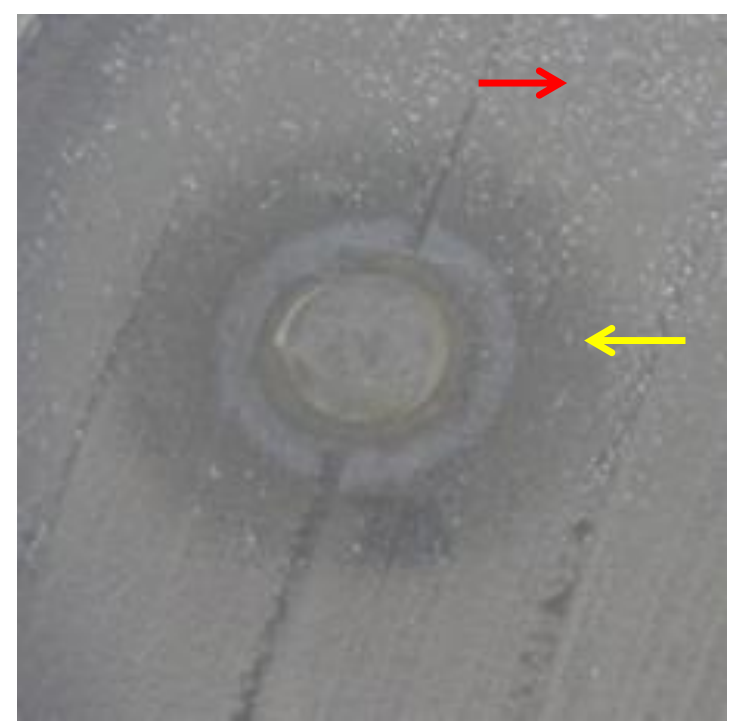

Figure 3. Antibacterial activity test results of BSL6 isolate against $S$. aureus. Note: Honeybee hive bacteria isolate indicate by red arrow, Inhibition zone formed indicate by yellow arrow

\section{Secondary metabolite test}

The results of secondary metabolite testing of BSL6 extract were shown in Table 4. This qualitative data showing the content of BSL6 secondary metabolites. The testing of secondary metabolite content in BSL6 was carried out in order to determine secondary metabolite compounds that act as antibacterials against $S$. aureus. Based on the results, only saponins contained in BSL6.

The results of the secondary metabolite test showed that BSL6 isolate contained saponins because bacterial extract formed foam when adding with distilled water and be shaken. The mechanism of saponins as antibacterials was that they could cause protein and enzyme leakage within cells. According to Madduluri et al. (2013), saponins could be antibacterial compounds because their surface-active agents were similar to detergents, consequently, saponins could reduce surface tension of bacterial cell walls and damage membrane permeability. According to Ningsih et al. (2016), saponins could diffuse through outer membrane and susceptible cell walls, then bound to cytoplasmic membrane so that they could disrupt and reduce the stability of cell membrane. This led to cytoplasmic leakage and resulted in the death of bacteria. Antimicrobial agents that interfere with cytoplasmic membranes are bactericidal.

Other secondary metabolite compounds such as alkaloids, steroids, terpenoids, flavonoids, phenolics, and tannins did not form. This was presumably because the bacterial extract used in secondary metabolite test was a liquid extract, which is an extract with low yield due to a large amount of water solvent contained and not evaporated, so that it was possible that the secondary metabolite compounds contained in bacteria extract were not expressed.

The conclusion that could be taken based on this study was that BSL6 isolate morphologically and physiologically belonged to the genus Bacillus, and 16S rDNA test results showed that the isolate had the highest similarity with $B$. siamensis strain 64X-5. BSL6 isolate was able to inhibit the growth of $S$. aureus with inhibition zone diameter of 17.87 $\mathrm{mm}$. MIC value of BSL6 against Staphylococcus aureus was at a concentration of $12.5 \%$. The content of secondary metabolite compounds from BSL6 extract was saponins.

\section{ACKNOWLEDGEMENTS}

The author would like to thank the Ministry of research and Technology/National Research and Innovation Agency (Indonesia) for the financial support through Basic Research Funding fiscal year 2020 (83/UN11.2.1/PT.01.03/ DRPM/2020).

\section{REFERENCES}

Bhorgin AJ, Uma K. 2014. Antimicrobial activity of earthworm powder (Lampito mauritii). Intl J Curr Microbiol Appl Sci 3 (1): 437-443.

Bisht R, Katiyar A, Singh R, Mittal P. 2011. Antibiotic resistance-a global issue of concern. Asian J Pharm Clin Res 2 (2): 34-39.

Bosshard PP, Abels S, Zbinden R, Böttger EC, Altwegg M. 2003. Ribosomal DNA sequencing for identification of aerobic grampositive rods in the clinical laboratory (an 18-Month Evaluation). J Clin Microbiol 42: 2065-2073.

Claverie JM, Notredame C. 2007. Bioinformatics for Dummies $2^{\text {nd }}$ ed. Wiley Publishing Inc., Indiana.

Cowan ST, Steel KJ. 1993. Manual for the identification of medical bacteria $3^{\text {rd }}$ Edition. Cambridge University Press, London.

Dantas Silva RP, Machado BAS, Barreto GdA, Costa SS, Andrade LN, Amaral RG, Carvalho AA, Padilha FF, Barbosa JDV,Umsza-guez MA. 2017. Antioxidant, antimicrobial, antiparasitic, and cytotoxic properties of various Brazilian propolis extracts. PLoS ONE 12 (3): e0172585. DOI: https://doi.org/10.1371/journal.pone.0172585.

Davis WW, Stout TR. 1971. Disc plate method of microbiological antibiotic assay. Appl Microbiol 22 (4): 659-665.

Dharmawan IWE, Retno K, Made SP. 2009. Isolation of Streptomyces spp. in Bali Barat National Park and inhibition test to five diarrheagenic Escherichia coli strain. Jurnal Biologi 13 (1): 1-6. [Indonesian]

Drancourt M, Bollet C, Carlioz A, Martelin R, Gayral JP, Raoult D. 2000. $16 \mathrm{~S}$ ribosomal DNA sequence analysis of a large collection of environmental and clinical unidentifiable bacterial isolates. J Clin Microbiol 38: 3623-3630.

Duniaji AS, Wisaniyasa NW, Puspawati NN. 2016. The potency of secondary metabolites of RJP bacteria in inhibiting the growth of Aspergillus flavus. Karya Tulis Ilmiah. Universitas Udayana, Bali. [Indonesian]

Holt JG, Krieg NR, Sneath PHA, Staley JT, William ST. 1994. Bergey’s Manual of Determinative Bacteriology $9^{\text {th }}$ Edition. William and Wilkins, Baltimore.

Kadaikunnan S, Rejiniemon TS, Khaled JM, Alharbi NS, Mothana R. 2015. In-vitro antibacterial, antifungal, antioxidant and functional of Bacillus amyloliquefaciens. J Ann Clin Microbiol Antimicrob 14: 918 .

Lay WB. 1994. Microbial Analysis in the Laboratory $1^{\text {st }}$ Edition. PT. Raja Grafindo Persada, Jakarta. [Indonesian]

Lofty M. 2006. Biological activity of bee propolis in health disease. Asian Pac J Cancer Prev 7 (1): 22-31.

Madduluri S, Rao KB, Sitaram B. 2013. In vitro evaluation of antibacterial activity of five indigenous plants extract against five bacterial pathogens of humans. Intl J Pharm Pharmaceut Sci 4: 679684.

Munfaati PN, Evie R, Guntur M. 2014. Antibacterial compounds activity of Phyllanthus niruri extract against the growth of Shigella dysenteriae in vitro. Lantera Biol 4 (1): 6471. [Indonesian]

NCBI. 2019. BLAST®. https://blast.ncbi.nlm.nih.gov/Blast.cgi 
Ningsih DR, Zusfahair, Kartika D. 2016. Identification of secondary metabolites compounds and antibacterial activities on the extract of soursop leaf. Molekul 11: 101-111. [Indonesian]

Nofiani R, Nurbetty S, Sapar A. 2009. Antimicrobial activity of methanol extract of sponge-associated bacteria from Lemukutan Island, West Kalimantan. E-Jurnal Ilmu dan Teknologi Kelautan Tropis 1: 33-41. [Indonesian]

Oonmetta-aree J, Suzuki T, Gasaluck P, Eumkeb G. 2005. Antimicrobial properties and action of Galangal (Alpinia galanga Linn.) on Staphylococcus aureus. Elsevier 39 (10): 1214-1220.

Pérez-Gutiérrez RA, López-Ramírez V, Islas A, Alcaraz LD, HernándezGonzález I, Olivera BCL, Olmedo-Alvarez G. 2013. Antagonism influences assembly of a Bacillus guild in a local community and is depicted as a food-chain network. ISME J 7 (3): 487-497.

Piccini C, Antunez K, Zunino P. 2004. An approach to the characterization of the honey bee hive bacterial flora. J Apic Res 43 (3): 101-104.

Promnuan Y, Kudo T, Chantawannakul P. 2009. Actinomycetes isolated from beehives in Thailand. World J Microbiol Biotechnol 25 (9): 1685-1689.

Rau CH, Yudistira A, Simbala HEI. 2018. Isolation, molecular identification using 16S rRNA gene, and antibacterial activity test of endophytic symbionts bacteria isolated from algae Halimeda opuntia. Jurnal Ilmiah Farmasi 7: 2302-2493. [Indonesian]

Reybroeck W, Daeseleire E, Barabander H, Herman L. 2012. Antimicrobials in beekeeping. Vet Microbiol 158: 1-11.

Soelama HJJ, Kepel BJ, Siagian KV. 2015. Minimum Inhibitory Concentration (MIC) test of seaweed extract (Eucheuma cottonii) as antibacterial against Streptococcus mutans. Jurnal e-GiGi 3: 374-379. [Indonesian]

Sumpavapol P, Tongyonk L, Tanasupawat S, Chokesajjawatee N, Luxananil P, Visessanguan W. 2010. Bacillus siamensis sp. nov., isolated from salted crab (phoo-khem) in Thailand. Intl J Syst Evol Microbiol 60: 2364-2370.

Sutton S. 2011. Measurement of microbial cells by optical density. J Validation Technol 17: 46-49.

Wachidah RN, Kholifa M, Sri R. 2016. The effect of giant honeybee (Apis dorsata) solution concentration on the growth inhibition of dominant gingivitis Porphyromonas gingivalis (In vitro study). Scientific Publications. Universitas Muhammadiyah Surakarta, West Java. [Indonesian]

Yuliana R, Sutariningsih E, Santoso HB, Hendarto KA, Riendrasari SD. 2015. Antimicrobial activity of honeybee Trigona spp hive against pathogenic microbial. Bioedukasi 8 (1): 67-72. [Indonesian] 